\title{
COLORS AND ENVIRONMENT
}

\author{
Padma Upadhyay \\ Dr. Saroj Mahajan \\ Govt MLB College, Indore
}

In last 50 years when the scientist become more aware about the environment as a whole, and started analyzing the data of water pollution, they were shocked to know that, $2 \%$ to $50 \%$ of synthetic dyes used are not utilized and go as a waste in effluents of industries. These dyes are highly soluble in water, resulting in the deterioration of COD and BOD content of the water stream, in which these effluents meet, affecting the flora and fauna of the concern region [3]. Since India is the major exporter and user of these synthetic dyes the situation is more alarming here.

History The man started using colored clays and minerals for the painting work in caves and their own bodies as early as Stone Age in Europe, India and China. Next came the use of colored fabric drawn from the insects and shell fish in Rome but due to costs involved, it was used by Royal families, rich and wealthy people only. Eventually by around $3000 \mathrm{BC}$, we evolved into using natural colors drawn from plants and vegetables and their parts like flowers, petals, seeds, fruits, barks, roots ( as per the evidence received from the cloths and earthen ornaments received from different civilization under excavation work) [5]. Nonetheless the global population was a lot lower, and use of colors was limited. Given the fact that the dyes used were from natural sources, and were bio-degradable, they did not have any major pollution effect on environment.This was the order of the day till the advent of industrialization era (after 1800 AD), when the synthetic dyes were invented, the processes were well documented, tested, exposed to different atmospheric conditions, for fastness of colors and repetition of process and suitability for mass production. These synthetic dyes became very popular and today we see around us, all the colored material - fabrics, furnishings, leather goods, buildings, plastics articles, metal parts, food items, etc. Colors are both almost indispensible as well as easily available. But if we see the story of the other side i.e. effect of these synthetic dyes on environment, we will be in for a surprise. In last 200 years, situation has denigrated to an alarming level.If today we do not act to reverse the process, to improve the environment, it could soon be too late. Though our ancestors have given us a healthy environment, we risk giving a polluted environment to our future generations.

\section{SYNTHETIC DYES AND THEIR EFFECT ON ENVIRONMENT}

Synthetic dyes are organic compounds, which pollutes the environment during their synthesis and later during the actual dyeing process. Particularly in textile industry, which utilizes the largest quantity of dyes, aqueous waste and dye effluents are discharged from the dyeing process, with both strong persistent color and high Biological Oxygen demand (BOD), both of which are aesthetically and environmentally unacceptable. In general the final textile waste water effluent based on Chemical Oxygen Demand (COD) content can be broadly categorized into three types namely High (1500mg/liter) Medium (970mg/liter) \& Low (460mg/liter) [3]. It is notable that 


\section{INTERNATIONAL JOURNAL Of RESEARCH -GRANTHAALAYAH

the standard value for COD for discharge of environment pollutant to inland surface water is maximum $250 \mathrm{mg} /$ liter [10]. The water specifications for drinking water and domestic use are still more stringent. Worldwide about $10^{6}$ tons of synthetic dyes are produced, of which, $1-1.5 \times$ $10^{5}$ tons are released in into the environment in waste waters. This release is due to that fact that not all dyes bind to fabric during the dyeing process which depends on the class of the dye. The losses in the waste water varies from $2 \%$ for basic dyes, to as high as $50 \%$ for reactive dyes, leading to severe contamination of the surface and ground waters in the vicinity of dyeing industries [3].Apart from the aesthetic point of view, synthetic dyes are undesirable because they can affect the living creatures. Synthetic dyes reduce the light penetration in the river or water body (lake, pond), and thus affect the photosynthesis activities of aquatic flora, thereby severely affecting the food source of aquatic organism. The thin layers of discharged dyes that form over the surfaces of the receiving water streams, also decreases the amount of Dissolved oxygen (DO), thereby affecting the aquatic fauna. Furthermore, dye containing effluents increases Biochemical Oxygen Demand.Synthetic dyes are in general stable organic pollutants that persist in the environment, and concern has been raised that such artificial compounds are Xenobiotic, therefore, methods for their degradation have been increasingly explored and under development.Despite the number of successful systems employing, various physiochemical and biological processes, economical removal of color from effluents remains a major problem. Unfortunately each process has its own constraints in terms of cost, feasibility, practicability, reliability, stability, environmental impact, sludge production, operational difficulty, pretreatment requirement and finally the extent of removal of organic and toxic byproduct. Also the use of single process, may not be completely decolorize the waste water and degrade the dye molecules. We all are aware that there is acute drinking water shortage predicted all over the world in coming decades, since the underground and surface water, is diminishing and deteriorating fast. We cannot afford to contaminate the existing sources of available water for drinking and domestic use. Natural sources of dyes could present an attractive alternative.Natural dyes and their Environment friendliness Natural coloring agents are mainly of in-organic in origin (clays, earths, minerals, metal salts, and even semiprecious stone such as malachite) or organic dye stuffs traditionally divided into two groups, one of the animal origins and another of plant origins.

Natural dyeing is an ancient art, which predates written records. It was practiced during the Bronze Age in Europe. Primitive dyeing techniques included sticking plants to fabric or rubbing crushed pigments to clothes. The methods become more sophisticated over time and techniques were developed using natural dyes from the crushed fruits, berries and other parts, which were boiled, along with the fabric or yarn and gave water and light fastness (resistance). In many of the world's developing countries, however, natural dyes can offer not only a rich and varied source of dye, but possibility of an income through sustainable harvest and sale of these dye plants. Many dyes are available from the tree waste or easily can be grown. In areas where synthetic dyes, mordants (fixatives) and other additives are imported and are therefore relatively expensive, natural dyes can offer an attractive alternative. In Ethiopia for example, there is a wealth of marigold flowers available for producing natural dyes, but due to lack of knowledge of the process involved in harvesting and processing of plants, little use is made of this environment friendly resource [1]. Similarly such environmentally friendly raw resources are available in 


\section{INTERNATIONAL JOURNAL Of RESEARCH -GRANTHAALAYAH \\ A knowledge Repository}

Art

practically all the tropical zones, we have to encourage their harvesting, arrange the collection of raw resource, develop the processes for dyeing such that quality of the product is as per requirement, and we can not only satisfy the color requirement of our people but save the environment for future generations. Table 1 presents various color dyes that can be sourced from various flowers. Table 2 presents a set of plants and their cultivation details in context of India.

\begin{tabular}{|c|c|c|c|}
\hline Color & Plant & Botanical name & Parts used \\
\hline \multirow[t]{7}{*}{ Red } & Safflower & Carthamus tinctorius $\mathrm{L}$. & Flower \\
\hline & Caesalpinia & Caesalpinia sappan $\mathrm{L}$. & Wood \\
\hline & Madder & Rubia tinctorium $\mathrm{L}$. & Wood \\
\hline & Log wood & $\begin{array}{l}\text { Haematoxylon campechianum } \\
\text { L. }\end{array}$ & Wood \\
\hline & Khat palak & Rumex dentatus $\mathrm{L}$. & Wood \\
\hline & Indian mulberry & Morinda tinctoria $\mathrm{L}$. & Wood \\
\hline & Kamala & Mallotus philippinensis Muell. & Flower \\
\hline \multirow[t]{5}{*}{ Yellow } & Golden rod & Solidago grandis DC. & Flower \\
\hline & Teak & Tectona grandis L.f & Leaf \\
\hline & Marigold & Tagetes $\mathrm{sp}$. & Flower \\
\hline & Saffrom & Crocus sativus $\mathrm{L}$. & Flower \\
\hline & $\begin{array}{l}\text { Flame of the } \\
\text { forest }\end{array}$ & $\begin{array}{l}\text { Butea monosperma (Lam) } \\
\text { Taubert. }\end{array}$ & Flower \\
\hline \multirow[t]{5}{*}{ Blue } & Indigo & Indigofera tinctoria $\mathrm{L}$. & Leaf \\
\hline & Woad & Isatis tinctoria $\mathrm{L}$. & Leaf \\
\hline & Suntberry & Acacia nilotica (L.) Del. & Seed pod \\
\hline & Pivet & Ligustrum vulgare L. & Fruit \\
\hline & Water lily & Nymphaea alba $\mathrm{L}$. & Rhizome \\
\hline \multirow{4}{*}{ Black } & Alder & Alnus glutinosa (L.) Gaertn. & Bark \\
\hline & Rofblamala & Loranthus pentapetalus Roxb. & Leaf \\
\hline & Custard apple & Anona reticulate $\mathrm{L}$. & Fruit \\
\hline & Harda & Terminalia chebula Retz. & Fruit \\
\hline \multirow{4}{*}{ Orange } & Annota & Bixa orellena L. & Seed \\
\hline & Dhalia & Dhalia sp. & Flower \\
\hline & Lily & Convallaria majalis $\mathrm{L}$. & Leaf \\
\hline & Nettles & Urtica dioica $\mathrm{L}$. & Leaf \\
\hline
\end{tabular}

Table 1: Natural sources for various colored dye [2], [11]

\begin{tabular}{|c|c|c|c|c|}
\hline Plant & Color & Pigment & Dye content & $\begin{array}{l}\text { Habitat } \\
\text { distribution }\end{array}$ \\
\hline $\begin{array}{l}\text { Acacia } \\
\text { catechu (L.f.) } \\
\text { Willd. }\end{array}$ & $\begin{array}{l}\text { Brown, } \\
\text { Black }\end{array}$ & $\begin{array}{l}\text { Catechin, } \\
\text { catechutanic acid }\end{array}$ & $\begin{array}{l}\text { The chief } \\
\text { constituents of heart } \\
\text { wood vary from } 4 \text { to } \\
7 \% \text { and are }\end{array}$ & $\begin{array}{l}\text { Pan India in dry mixed } \\
\text { forest, across various } \\
\text { soil types. }\end{array}$ \\
\hline
\end{tabular}




\section{INTERNATIONAL JOURNAL Of RESEARCH -GRANTHAALAYAH

\begin{tabular}{|c|c|c|}
\hline $\begin{array}{l}\text { Adhatoda } \\
\text { vasica Nees. }\end{array}$ & Yellow & $\begin{array}{l}\text { Adhatodic ac } \\
\text { carotein, luto } \\
\text { quercetin }\end{array}$ \\
\hline $\begin{array}{l}\text { Bixa orellena } \\
\text { L. }\end{array}$ & $\begin{array}{l}\text { Orange, } \\
\text { Red }\end{array}$ & Bixin, norbixin \\
\hline
\end{tabular}

$\begin{array}{ll}\begin{array}{l}\text { Butea } \\ \text { monosperma } \\ \text { (Lam) }\end{array} & \begin{array}{l}\text { Yellow, Butrin } \\ \text { Orange }\end{array} \\ \end{array}$

Taubert.

Carthamus Yellow, Carthamin tinctorious L. Red

Curcuma Yellow Curcumin longa $\mathrm{L}$.

Indigofera Blue Indigotin, Indican tinctoria $\mathbf{L}$.

Lawsonia Orange Lawsone inermis $\mathrm{L}$. distributed

throughout the heart wood from the root to branches

-
philippensis Red Rottlerin Muell. Morinda
The dye content is 5$6 \%$ by weight of seed. A carotenoid bixin comprises 70 $80 \%$ in each seed.

Carthamin ranges from $3-6 \%$ in the flower

Curcumin ranges from $5.4-8.7 \%$

While indigotin varies from season to age of plant, best grade can see 70 $80 \%$ in dried leaves.

Lawsone is present While it grows best on in dried leaves at 1- heavy soil, but can grow $1.4 \%$ on any soil from light loam to clay loam. Cultivated in Tamil Nadu, Madhya Pradesh \& Rajasthan. $1.4-3.7 \%$ in fruits

Pan India upto altitude of $1300 \mathrm{~m}$. Grows on waste land and sometimes cultivated as hedge

While native to tropical America found in hotter parts of India at 600-900 $\mathrm{m}$.

Pan India, especially on black cotton soil, also on saline, alkaline, swampy and barren lands.

Pan India, but on fertile moisture retaining and well drained soils.

Cultivated on well drained, fertile, sandy, clayey, black and red soil upto $1200 \mathrm{~m}$.

Tropical regions

Sal and mixed forests pan India. Also seen till $1500 \mathrm{~m}$ on outer Himalayas.

Dye is sourced from Small tree distributed 


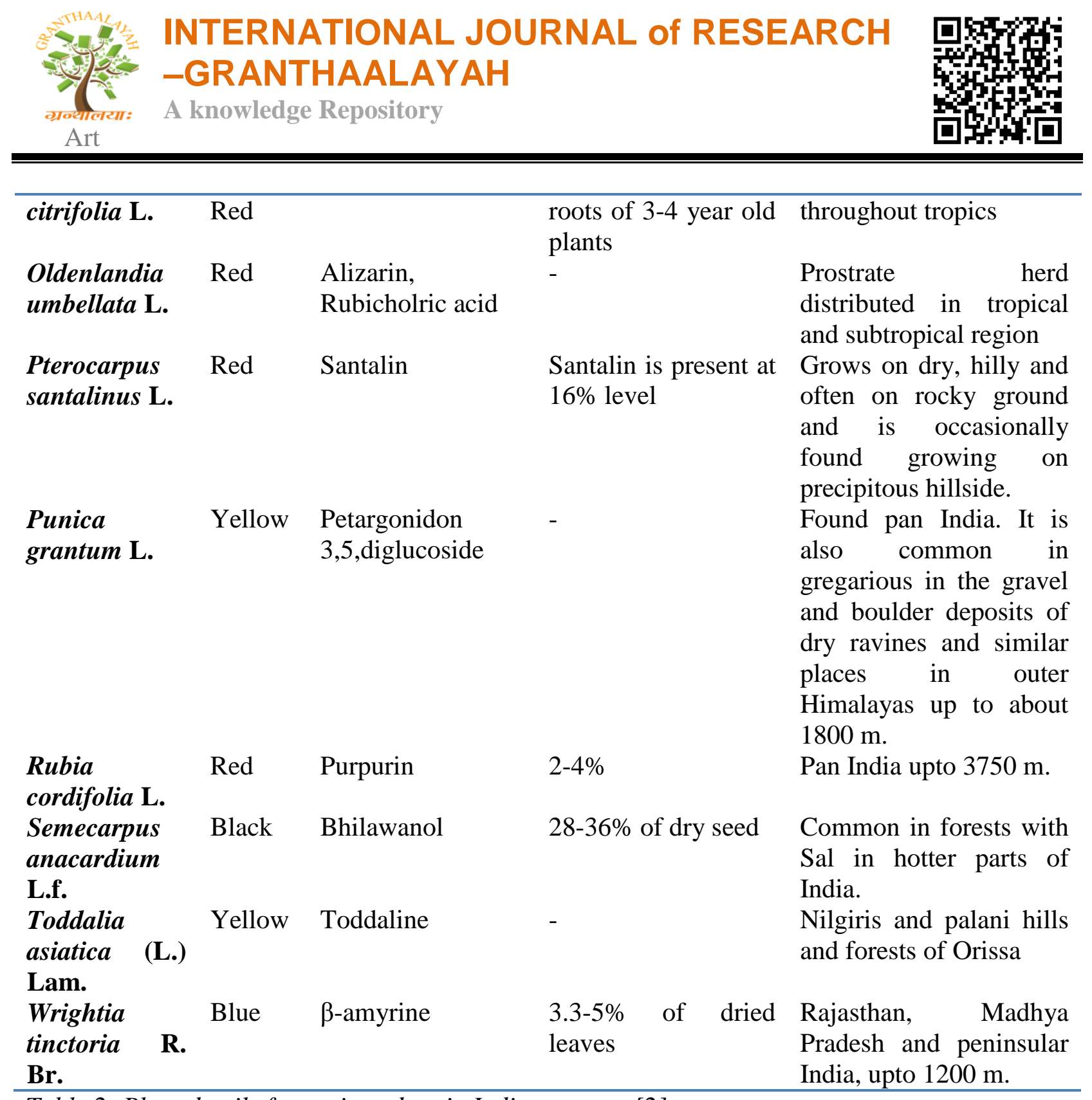

Table 2: Plant details for various dyes in Indian context [2]

From mid of 1980's scientist, researchers, and environmentalist are trying hard to reverse the process to save the environment but now they have succeeded in drawing the attention of the general people and Governments. So now the laws are more rigid and people are gradually favoring the environment friendly products.World can be divided on different climate zones, depending on their height of land from sea level, average rainfall, type of soil, and other climate conditions. Depending on all this factors, the flora, fauna and crops from that area varies from lace to place. If we look in the history, the tribal people and other local residents of a particular local area, have extracted the color pigments from the available natural sources, utilized it for fulfilling their requirement, without affecting the environment adversely for centuries. The only drawback was, they have not documented the procedures, and information was passed by one generation to another.Secondly since the dyeing raw material is different in different regions, so 


\section{INTERNATIONAL JOURNAL Of RESEARCH -GRANTHAALAYAH \\ A knowledge Repository}

Art

we have to look in to the improvement of the processes, so we can develop the better natural dye products.Thirdly the developed dye should perform, in a consistent manner. But the quality of dye depends on the raw material used, and since the raw material used is the plants, so we have to look in to the soil conditions and other factors responsible for the growth of the plants. So we either modify the process such that we can consistently get the same quality product or we have to categorize the product in different categories. Since India is the country, which is top ranked in synthetic dye exports, and we have practically all the climate zones (a gift from nature) to cultivate the entire range of plants, and presently the world is favoring the environmental friendly products and is even ready to pay the higher cost for the same, we can probably take a lead role and utilize this opportunity for the growth of natural dyes and save our environment and world environment as a whole.

\section{CONCLUSION}

Scientific methods, for extraction and behavior, are yet to be established for majority of natural dyes, as well as, purification of colorant, colorfastness, hue color with different mordant, different treatment like enzyme treatment, bio-moderating and color stability are some of the areas which have not been studied in detail.Demand of natural color can be greatly increased in textiles, cosmetics, leather, food and pharmaceutical industries.It is high time to switch over to natural dyes, so we can preserve the environment, which is not only required for the human race, but equally important for all the living organisms.

\section{REFERENCES}

1 D. Jothi, Extraction of natural dyes from African marigold flower(Tagets Ereecta) for textile coloration, AUTEX Research Journal, Vol 8, 2, June 2008,49-53

2 R. Siva Status of Natural Dyes and dye-yielding plants in India Current Science, Vol 92 , 7, April 2007, 916-925

3 L. Pereira and M. Alves, Dye-Environmental Impact and remediation Ratna, Padhi B.S. Pollution due to Synthetic dyes, toxicity \& carcinogenicity studies and remediation, International journal of Environmental Sciences, Vol 3,3, 2012, 940-955

4 Chavity Goetz, textile dyes - techniques and their effect on the Environment with a recommendation for dyers concerning the green effect, Liberty University

5 Indian Standards Specification for drinking water IS: 10500 and its amendments.

6 List of NABL accredited analytical parameters for water and waste water laboratory. 